\title{
Energy performance of residential buildings and their architectural configuration
}

\author{
İlknur Erlalelitepe ${ }^{1}$, Kenan Evren Ekmen², Cihan Turhan², Manolya Akdemir², Gülden Gökçen \\ Akkurt $^{3}$, Tuğçe Kazanasmaz ${ }^{1^{*}}$ \\ ${ }^{I}$ Izmir Institute of Technology, Department of Architecture, İzmir, Turkey \\ ${ }^{2}$ Izmir Institute of Technology, Energy Engineering Program, İzmir, Turkey \\ ${ }^{3}$ Izmir Institute of Technology, Department of Mechanical Engineering, İzmir, Turkey \\ *Corresponding author.Tel: +907507063, Fax:+907507012, E-mail: tugcekazanasmaz@iyte.edu.tr*
}

\begin{abstract}
This study was conducted to determine a significant relationship between energy performance of residential buildings and their architectural configuration. It is known that there are high amount of energy expenses of residential buildings while they are in use. Utilizing knowledge to decrease costs in housing construction and energy consumption during their lifetime, it has been worth to study this subject here. Case study examples were selected from residential buildings in İzmir, Turkey, which were 5-11 storey-blocks with various construction dates. Utilizing architectural and mechanical production drawings, certain area-based ratios and building dimensions were determined as architectural configuration indicators. Energy performance of case buildings were determined by using a calculation method according to the Thermal insulation Requirements for Buildings-TS825. The significant relationship between architectural configuration aspects and energy performance of buildings were analyzed through statistical analysis and scatter charts. Findings were discussed on the basis of TS825. Thus, instead of renovation of existing buildings' energy performance by limited solutions (to add insulation material etc.), taking simple and inexpensive precautions in design process and their application might provide a wide energy saving potential.
\end{abstract}

Keywords: Energy performance, Design efficiency, Architectural, Residential buildings.

\section{Introduction}

Energy efficiency has been a critical issue to design residential buildings of good quality, all over the world, and in Turkey as well. It is a high indicator of thermal and visual comfort, and also a significant and powerful impact on energy costs. Due to sheltering needs of increasing population and providing a qualified habitat, the field of housing design is rife with proposals that lay claim in improving efficiency [1-3]. As the residential heating is the main source for energy and resource consumption in Turkey, residential design has gained utmost concern nowadays to reduce energy and resource consumption. Utilizing dwellings offering comfortable interior spaces, it would also be possible to reduce harmful gases released into the environment [4-6].

It is clear in literature that architectural configuration of buildings and design norms have direct impact on energy performance of buildings. Several studies have been conducted about thermophysical characteristics of the exterior walls, building orientation and geometry, building location together with energy efficiency of buildings [7-10]. In a study, for example, optimum window dimensions and heat insulation with an optimum thickness together resulted in a high energy performance among case buildings [11]. In another study, the impact of glass types and overhangs on the heat conductance of wall and roofs were analyzed [12].

Studies on energy rating offered a variety of methods and software (design tools) to design and analyze energy efficient indoor environments [13-18]. Especially the attempt of construction sector consuming high energy in developed countries was to take measures and programs to 
rationalize energy consumption in residential buildings. The main objective was to reduce energy consumption for heating [1-3]. To achieve this goal, the design and evaluation process should be in accordance with the proposed method [19]. Considering the lack of comprehensive studies on the relations of energy performance and architectural parameters of buildings in Turkey, a detailed research has been conducting in Izmir and the initial findings will be discussed here.

From the beginning of the 1990s, the Member States in Europe dealt with the legal regulations about energy consumption in order to reduce carbon dioxide emissions, according to Kyoto Protocol. Turkey is now responsible to provide regulations to comply for the latest European Energy Performance of Buildings Directive 2010/31/EC. [20]. In particular, the Thermal insulation requirements for buildings-TS825 and Heat Insulation Regulation (2000) were legally adopted in 2000: the latter is the complementary regulation of the former which offers the calculation method for the energy demand for heating in buildings [21]. Heat Insulation Regulation sets rules for all buildings to reduce heat loss, to provide energy saving and to determine application guideline [22]. Turkey complied with the rules by Directive 2010/31/EC, through Energy Efficiency Law (2007) and Building Energy Performance Regulation (2008). As regards these regulations, following actions were proposed: the evaluation for the energy consumption of buildings, the classification of buildings, determination of minimum energy performance requirements of existing buildings for their renovation [23,24]. "Standard Assessment Method for Energy Performance of Buildings" has been developed by The Ministry of Public Works and is expected to be published in January 2011. It will be legally adopted and will draft energy certificate and compare the energy performance of a building with ascertained energy limits. This method will include heating, cooling, domestic hot water production, lighting energy consumptions and $\mathrm{CO}_{2}$ emissions. This study, however, included the calculation method which is currently in use.

Design efficiency in architecture is a concept to design and construct buildings and spaces inside more efficiently. It is derived from architectural configuration factors. By this way, it provides construction and maintenance costs at an optimum level. Energy performance is an indicator for the energy cost of the building and for the visual and thermal comfort conditions of users, as well. Again, Turkey, preparing legislations for energy performance, is responsible to ensure compliance of 2010/31/EC and these legislations offer to conduct several studies for new and existing buildings in a 10-year-period. In view of these resent research and ongoing knowledge, this study was constructed for residential buildings in İzmir, which is the third most populated city of Turkey to analyze their energy performance and architectural configuration. The objective is to determine relations between energy performance of residential buildings and their design efficiency. Energy performance of case buildings were determined by using a calculation method defined by TS825. The significant relationship between architectural configuration aspects and energy performance of buildings were determined through statistical analysis and scatter charts. To rank buildings according to their energy performance, the ratio of calculated energy demand to maximum allowed energy demand defined in TS825 were used.

\section{Methodology}

\subsection{Residential buildings in İzmir}

Case study examples were selected from İzmir which is situated in the western part of Turkey (latitude $38^{\circ} 25^{\prime} \mathrm{N}$, longitude $27^{\circ} 08^{\prime} \mathrm{E}$ ), along the Gulf of İzmir, by the Aegean Sea. İzmir has a 
typical Mediterranean climate which is characterized by long, hot and dry summers; and mild to cool, rainy winters. The average minimum temperatures during winter months vary between 6 and $8^{\circ} \mathrm{C}$. Average daytime temperatures, however, during summer months (May to October) are almost $25^{\circ} \mathrm{C}$ or higher.

To determine case buildings, Building Construction Statistics by Turkish Statistical Institute were analyzed. According to these, the number of multi-story residential buildings is $40 \%$ of the whole residential buildings constructed from 1960s to 2008, in İzmir. This rate tends to increase because of increasing population and lack of construction area. Thus, subject buildings in this study were defined to be 5-11 storey residential buildings. A total of 30 buildings were selected from three municipalities due to variation in zoning status and high construction rate. Among these, ten out of 30 were in Konak (designated as $\mathrm{K} 1, \mathrm{~K} 2, \ldots$ ), the other ten were in Karabağlar (designated as Ka1,Ka2...), and the rest in Balçova (designated as Ba1,Ba2...). Architectural and mechanical production drawings were obtained from archives of related municipalities. Buildings were classified with reference to zoning status, orientation, floor number, designer and construction year. The data obtained from drawings included address, construction year, number of flats, floor number, zoning status, designer's professional status, width and height of the building, total floor area, total floor area of common spaces, total volume, total area of façade. The principal aim of this study was to analyze existing residential buildings in İzmir with respect to their architectural configuration as a representative tool for their energy performance. It was also thought that results of this analysis would provide much-needed feedback for designers and professionals in İzmir and in other cities.

\subsection{Architectural configuration indicators}

Relevant attributes of the architectural configuration are basically building form, orientation, zoning status together with several building envelope factors and climate [7-11]. In addition to data cited in previous section, relevant areas of architectural configuration calculated from drawings in this study were the following: net-usable floor area (inclusive of all internal areas left out from footprint area of all structural elements); external surface area(calculated from external perimeter and the floor to ceiling height of residential building); net-usable common floor area (the exclusive of all residential flats from net-usable floor area); window area (area where high amount of heat would be gained/lost); external wall area and external dimension(width and length). Architectural configuration indicators, as shown in Table 1, were, then, offered to conduct the assessment for the occurrence of significant relations between energy performances and architectural configuration of buildings. These ratios derived from above areas are described below;

Ratio of external surface area to net usable floor area: This is an indicator that reflects form of building by its volume in zoning status. So it is highly related in exterior surface design and in cost efficiency of energy consumption by concerning surfaces. Ratio of window area to external surface area: This was viewed as the indicator for the equilibrium of solid-void, describing effects of void surfaces to hold minimum heat load. Ratio of width to length: This is an indicator of plan configuration. The objective here was to determine maximum utility spaces and building surfaces in suggested zoning plan. Ratio of external wall area to net-usable area: This ratio was used to define design efficiency indicator related flexibility, utility and cost efficiency of designed spaces. It is the one of the general design principle, creating minimum wall area and 
minimum fragment plan scheme. Ratio of net-usable common floor area to net-usable floor area: Minimum common spaces have great potential on useful spaces to make them usable and generative. It is related in management cost of first and after construction.

Table 1 Architectural configuration indicators(Balçova:Ba, Konak:K, Karabağlar:Ka)

\begin{tabular}{|c|c|c|c|c|c|}
\hline $\begin{array}{l}\text { Build } \\
\text { no. }\end{array}$ & $\begin{array}{l}\text { building } \\
\text { surface/ net- } \\
\text { usable area }\end{array}$ & $\begin{array}{l}\text { window } \\
\text { area/ } \\
\text { building } \\
\text { surface }\end{array}$ & $\begin{array}{c}\text { width } \\
\text { /length }\end{array}$ & $\begin{array}{c}\text { wall } \\
\text { surface/ } \\
\text { net- } \\
\text { usable } \\
\text { area }\end{array}$ & $\begin{array}{c}\text { net-usable } \\
\text { common floor } \\
\text { area/ net-usable } \\
\text { area }\end{array}$ \\
\hline Ba1 & 1,86 & 0,22 & 0,54 & 1,45 & 0,11 \\
\hline $\mathrm{Ba} 2$ & 0,87 & 0,22 & 0,69 & 0,68 & 0,04 \\
\hline Ba3 & 0,50 & 0,35 & 0,88 & 0,32 & 0,06 \\
\hline Ba4 & 1,09 & 0,17 & 0,67 & 0,90 & 0,15 \\
\hline Ba5 & 1,02 & 0,13 & 0,88 & 0,88 & 0,06 \\
\hline $\mathrm{Ba} 6$ & 1,19 & 0,16 & 0,99 & 1,00 & 0,09 \\
\hline Ba7 & 0,74 & 0,21 & 0,29 & 0,59 & 0,09 \\
\hline Ba8 & 0,64 & 0,30 & 0,56 & 0,44 & 0,10 \\
\hline Ba9 & 0,90 & 0,19 & 0,51 & 0,57 & 0,07 \\
\hline $\mathrm{Ba} 10$ & 0,84 & 0,18 & 0,67 & 0,69 & 0,11 \\
\hline K1 & 0,59 & 0,16 & 0,52 & 0,50 & 0,10 \\
\hline K2 & 0,32 & 0,46 & 0,71 & 0,17 & 0,06 \\
\hline K3 & 1,09 & 0,15 & 0,40 & 1,15 & 0,02 \\
\hline K4 & 0,17 & 0,38 & 0,41 & 0,07 & 0,03 \\
\hline K5 & 0,55 & 0,32 & 0,61 & 0,37 & 0,04 \\
\hline K6 & 0,51 & 0,34 & 0,79 & 0,34 & 0,03 \\
\hline K7 & 0,50 & 0,57 & 0,59 & 0,21 & 0,06 \\
\hline K8 & 0,99 & 0,15 & 0,36 & 1,05 & 0,02 \\
\hline K9 & 0,74 & 0,31 & 0,80 & 0,51 & 0,10 \\
\hline K10 & 0,61 & 0,42 & 0,45 & 0,35 & 0,10 \\
\hline Ка 1 & 0,31 & 0,37 & 0,39 & 0,20 & 0,04 \\
\hline Ka 2 & 0,73 & 0,42 & 0,37 & 0,42 & 0,08 \\
\hline Ка 3 & 0,30 & 0,54 & 0,36 & 0,14 & 0,09 \\
\hline Ка 4 & 0,56 & 0,39 & 0,54 & 0,34 & 0,05 \\
\hline Ka 5 & 0,64 & 0,56 & 0,58 & 0,28 & 0,07 \\
\hline Ка 6 & 0,57 & 0,55 & 0,50 & 0,26 & 0,09 \\
\hline Ка 7 & 0,40 & 0,48 & 0,52 & 0,21 & 0,06 \\
\hline Ка 8 & 0,69 & 0,36 & 0,46 & 0,44 & 0,05 \\
\hline Ка 9 & 0,59 & 0,37 & 0,48 & 0,37 & 0,05 \\
\hline Ка 10 & 0,02 & 0,40 & 0,49 & 0,01 & 0,00 \\
\hline
\end{tabular}

\subsection{Thermal Insulation Requirements for Buildings -TS 825}

TS 825 [21] "Thermal Insulation Requirements for Buildings” is an official obligatory standard of Turkey derived from DIN V 18599. TS 825 has been in use since 2000 which is revised in 
2008 by lowering maximum allowable total heat transfer coefficient. Main purpose of TS 825 is to limit building's energy demand according to exposed area to volume (A/V) ratio. TS 825 uses solar radiation and outdoor air temperature values which are tabulated according to climatic regions specifically determined for Turkey using degree-day method. Heat demand is calculated monthly including specific heat loss, efficiency factor, internal and solar gains. Thermal bridging effect is taken into account with length of the element (I) and longitudinal heat loss coefficient $\left(\mathrm{U}_{\mathrm{L}}\right)$ according to TS EN ISO 14683 (2004). In TS 825, internal gains are simplified as $5 \mathrm{~W} / \mathrm{m}^{2}$ for net floor area. Gain utilization factor $(\eta)$ is used to correct the total of internal and solar gains to calculate average monthly useful gains in a statistical way. Calculation of yearly heat demand is followed by comparison of limiting values given in TS 825 according to $\mathrm{A} / \mathrm{V}$ ratio. If the yearly heat demand is within the limits, the procedure is completed; otherwise properties of the building elements should be re-evaluated and re-calculated.

\subsection{Statistical Analysis}

The relations between variables, namely, ratio of external surface area to net usable floor area, ratio of window area to external surface area, ratio of width to length, ratio of external wall area to net-usable area, ratio of net-usable common floor area to net-usable floor area and energy performance ratio were tested by single-factor ANOVA at a 5\% level of significance $(\alpha=0.05)$. Scatter plots were derived from paired values of variables, namely, heating energy demand, ratio of building surface area to net usable floor area, ratio of window area to external surface area, ratio of width to length, net-usable common floor area to net-usable floor area. These were constructed to understand the relation between architectural configuration indicators and heating energy demand.

\section{Results and Discussion}

\subsection{Findings obtained from TS825.}

The results of calculation method-TS825 were tabulated according to construction year, orientation and zoning status. Here, external surface area per volume, heat loss, solar gain, calculated energy demand, max. energy demand, energy performance ratio, and annual fuel demand were tabulated according to construction year as shown in Table 2. In the analysis, heat loss through ventilation and heat gain from internal environment were also calculated. Energy performance ratio of 9 buildings range from 0,94 to 1,00, while 11 of them were from 1,03 to 1,92. Rest of the buildings' energy performance ratio varies between 2,14 and 2,88. Most of the buildings with high energy performance were situated in Balçova. They were the recently constructed buildings according to construction year. However, buildings constructed mostly in 1970s in Karabağlar were having low energy performance.

\subsection{Findings obtained from statistical analysis.}

The null hypothesis was $\mathrm{H}_{0}: \tau_{\mathrm{i}}=0$; there is no relation among energy performance according to ratio of window area to external surface area. Accordingly, $\mathrm{H}_{0}$ was accepted at $5 \%$ level of significance. It was concluded that ratio of window area to external surface area did not varied significantly according to energy performance. All findings showed that there was no relation between architectural configuration indicators mentioned above and energy performance ratio. Scatter charts also supported this result. 
Table 2 Building energy performance data obtained from TS825 according to construction year

\begin{tabular}{|c|c|c|c|c|c|c|c|c|}
\hline Year & $\begin{array}{c}\text { build. } \\
\text { no }\end{array}$ & $\mathrm{A} / \mathrm{V}$ & $\begin{array}{c}\text { heat } \\
\text { loss } \\
(\mathrm{W} / \mathrm{K})\end{array}$ & $\begin{array}{l}\text { solar } \\
\text { gain } \\
\text { (W) }\end{array}$ & $\begin{array}{c}\text { calculated } \\
\text { energy } \\
\text { demand } \\
\left(\mathrm{kWh} / \mathrm{m}^{3}\right)\end{array}$ & $\begin{array}{c}\text { max. energy } \\
\text { demand } \\
\left(\mathrm{kWh} / \mathrm{m}^{3}\right)\end{array}$ & $\begin{array}{l}\text { energy per. } \\
\text { ratio } \\
\text { cal.energy/ } \\
\text { max.energy }\end{array}$ & $\begin{array}{c}\text { annual } \\
\text { fuel } \\
\text { demand } \\
(\mathrm{kg})\end{array}$ \\
\hline $\begin{array}{l}1960- \\
1969\end{array}$ & K9 & 0,42 & 1169,70 & 61276 & 18,00 & 9,36 & 1,92 & 7291,54 \\
\hline \multirow{7}{*}{$\begin{array}{l}1970- \\
1979\end{array}$} & Ka 10 & 0,18 & 2638,28 & 94290 & 13,25 & 6,20 & 2,14 & 19721,04 \\
\hline & Ka 5 & 0,34 & 3761,00 & 371190 & 12,49 & 8,24 & 1,52 & 18721,95 \\
\hline & Ка 6 & 0,32 & 4874,74 & 307516 & 21,48 & 7,95 & 2,70 & 28624,84 \\
\hline & Ка 7 & 0,27 & 3531,69 & 161045 & 20,29 & 7,22 & 2,81 & 23744,44 \\
\hline & Ка 8 & 0,37 & 3681,05 & 155100 & 23,76 & 8,59 & 2,77 & 22747,55 \\
\hline & Ка 3 & 0,23 & 2078,27 & 104923 & 17,04 & 6,64 & 2,57 & 14156,78 \\
\hline & Ka 4 & 0,28 & 4106,35 & 224229 & 15,98 & 6,51 & 2,45 & 25889,27 \\
\hline \multirow{12}{*}{$\begin{array}{l}1980- \\
1989\end{array}$} & BA1 & 0,37 & 2399,00 & 134625 & 13,48 & 8,67 & 1,55 & 16055,33 \\
\hline & BA2 & 0,44 & 2827,20 & 108958 & 21,04 & 9,65 & 2,18 & 19688,14 \\
\hline & K3 & 0,49 & 2144,20 & 101650 & 13,43 & 10,35 & 1,30 & 14323,37 \\
\hline & K4 & 0,19 & 1642,00 & 122282 & 9,25 & 6,20 & 1,49 & 10493,66 \\
\hline & K7 & 0,13 & 1945,20 & 191959 & 5,84 & 6,20 & 0,94 & 13818,38 \\
\hline & K10 & 0,28 & 2885,90 & 175195 & 9,83 & 6,22 & 1,58 & 8424,46 \\
\hline & K8 & 0,35 & 2325,10 & 101560 & 10,95 & 8,38 & 1,31 & 16829,06 \\
\hline & K6 & 0,29 & 3456,60 & 275989 & 9,05 & 9,05 & 1,00 & 21982,30 \\
\hline & K5 & 0,39 & 1540,40 & 156551 & 11,19 & 10,82 & 1,03 & 8507,13 \\
\hline & Ка 9 & 0,33 & 4362,80 & 198601 & 22,77 & 7,98 & 2,85 & 28731,50 \\
\hline & Ка 1 & 0,23 & 1724,94 & 62394 & 14,46 & 6,66 & 2,17 & 12817,99 \\
\hline & Ka 2 & 0,39 & 3912,23 & 209748 & 25,44 & 8,84 & 2,88 & 24115,27 \\
\hline \multirow{3}{*}{$\begin{array}{l}1990- \\
1999\end{array}$} & BA3 & 0,23 & 3483,80 & 244071 & 9,77 & 6,60 & 1,48 & 10473,92 \\
\hline & K1 & 0,37 & 344,90 & 15174 & 9,90 & 8,63 & 1,15 & 2640,02 \\
\hline & K2 & 0,14 & 2247,30 & 113928 & 6,10 & 6,20 & 0,98 & 21462,84 \\
\hline \multirow{7}{*}{$\begin{array}{c}2000- \\
2009\end{array}$} & BA4 & 0,61 & 441,09 & 38941 & 11,95 & 11,55 & 1,03 & 3370,58 \\
\hline & BA5 & 0,27 & 2655,97 & 39810 & 9,15 & 9,54 & 0,96 & 5470,00 \\
\hline & BA6 & 0,43 & 1047,77 & 32318 & 11,27 & 11,92 & 0,95 & 23250,00 \\
\hline & BA7 & 0,33 & 1909,56 & 114991 & 7,90 & 7,98 & 0,99 & 15003,07 \\
\hline & BA8 & 0,44 & 1001,88 & 74182 & 8,77 & 9,17 & 0,96 & 7239,95 \\
\hline & BA9 & 0,49 & 951,31 & 52132 & 9,86 & 10,24 & 0,96 & 6712,55 \\
\hline & BA10 & 0,73 & 464,34 & 38135 & 13,06 & 13,64 & 0,96 & 3412,85 \\
\hline
\end{tabular}

\section{Conclusions and Recommendations}

The analyses of variance and scatter charts were applied to determine relation between architectural configuration indicators and energy performance of residential buildings. Energy demand calculations were constructed by TS 825. A number of results about architectural configuration indicators and their relationship with energy performance ratio were considered as noteworthy on their own merit. One was that the energy performance ratio was independent of 
architectural configuration indicators, despite literature [7-14], showing distinct impact of architectural aspects on building energy performance. Another noteworthy observation was the independence of zoning status and orientation on the energy performance ratio. Several conditions may indicate such an anomaly. One is that the study included a limited number of sample buildings. The other one is that the calculation method is independent from orientation, building form. TS 825 , as a static method, is well established to control overall heat transfer coefficient and limit heating energy demand of a building. However, using monthly average climatic values, single zone assumption, ignoring thermal mass, assuming continuous heating regime, lack of internal gain details and control of HVAC systems leads inaccurate results compared with measurements. Results of the static methods give an estimate of monthly heating load and idea about applicable measures to reduce the heat loss of the building. On the other hand, dynamic methods calculate gains and losses from different elements in a building, giving details about different zones and their interactions with the building. Therefore, once the dynamic method which has been developed for building energy performance for Turkey is released, this study will be repeated accordingly. The authors hoped that the new method will exhibit the relationship with building energy performance and architectural parameters. It is necessary to conduct further investigations with inclusion of high number of sample buildings in Turkey. Then, all findings which will be resulted by objective evaluations about existing buildings will be presented to all correspondings' knowledge and use.

\section{Acknowledgements}

The Scientific and Technological Research Council of Turkey (TÜBİTAK) funded this research and their contribution is gratefully acknowledged.

\section{References}

[1] M. Santamouris, Introduction On the Energy Rating of Buildings, in Energy Performance of Residential Buildings, James \& James/Earthscan, UK, 2005.

[2] J. Smeds, and M. Wall, Enhanced Energy Conservation in Houses through High Performance Design, Energy and Buildings, 39, 2007, pp. 273-278.

[3] I. Borden, A. Leaman A. and M. Atkins, Energy efficient design, A Guide to Energy Efficiency and Solar Applications in Building Design, United Nations, New York, 1991.

[4] E. Berköz and G. Kocaaslan, Enerji ve Kaynak Tüketimini azaltan Konut ve Yerleşme Tasarım1, Konutta Kalite, Derleyen T. Aktüre, MESA, Ankara, 1994, pp. 141-156.

[5] M. Balamir, Kentleşme, Kentsel süreçler ve kent yapısı, ODTÜ Mimarlık Fakültesi, Ankara, 1982.

[6] V. İmamoğlu, Konutlarda Isı Konforu, Konutta Kalite, Derleyen; T.Aktüre, MESA, Ankara, 1994, pp. 105-116.

[7] R. Ünver, N.Y. Akdag,, G.Z. Gedik, L.D. Öztürk and Z. Karabiber, Prediction of building envelope performance in the design stage: an application for office buildings, Building and Environment, 39, 2004, pp. $143-152$.

[8] G. K. Oral, A.K. Yener, N.T. Bayazit, Building envelope design with the objective to ensure thermal, visual and acoustic comfort conditions, Building and Environment, 39, 2004, pp. $281-287$. 
[9] G.K. Oral, and Z. Y1lmaz, The limit U values for building envelope related to building form in temperate and cold climatic zones, Building and Environment, 37, 2002, pp. 1173 - 1180.

[10]G. Manioğlu and Z. Yilmaz, Energy Efficient Design Strategies in the Hot Dry Area of Turkey, Building and Environment, 43, 2008, pp. 1301-1309.

[11]M.N. İnanıcı and F.N. Demirbilek, Thermal Performance Optimization of Building Aspect Ratio and South Window Size in Five Cities Having Different Climatic Characteristics of Turkey, Building and Environment, 35, 2000, pp. 41-52.

[12] G.A. Floridesa, S.A. Tassoub, S.A. Kalogiroua and L.C. Wrobelb, Measures Used to Lower Building Energy Consumption and Their Cost Effectiveness, Applied Energy, 73, 2002, pp. 299-328.

[13] S. Alvarez, A. Blanco, J.A. Sanz, F.J. Sanchez, The Euroclass method-description of the software, in Energy Performance of Residential Buildings, Ed.M.Santamouris, James \& James/Earthscan, UK, 2005.

[14]B. Poel, G. Cruchten, and C. Balaras, Energy performance assessment of existing dwellings, Energy and Buildings, 39, 2007, pp. 393-403.

[15]L. Pedersen, Use of different methodologies for thermal load and energy estimations in buildings including meteorological and sociological input parameters, Renewable and Sustainable Energy Reviews, 11, 2007, pp. 998-1007.

[16]TOBUS.About EPIQR.Visited on: January 6, 2007. Available at:

[http://tobus.cstb.fr/english/epiqr.htm].

[17]C.A. Balaras, K. Droutsa, A.A. Argiriou and D.N. Asimakopoulos, EPIQR surveys of apartment buildings in Europe, Energy and Buildings, 31, 2000, pp. 111-128.

[18]SAP2005, The Government's Standard Assessment Procedure for Energy Rating of Dwellings, 2005 Ed., Revision 1, Version 9.81, 2008.

[19] International Energy Agency (IEA), Integral Building Envelope Performance Assessment, Technical Synthesis Report IEA ECBCS Annex 32, Energy Conservation in Buildings and Community System, FaberMaunsell Ltd., United Kingdom, 2003.

[20]DIRECTIVE 2010/31/EC of the European Parliament and of the Council on the Energy Performance of Buildings, 2010.

[21]Anon. the Thermal Insulation Requirements for Buildings -TS825, Ankara: Turkish regulations, 1999 (in Turkish)

[22] Anon. Heat Insulation Regulation, Ankara: Ministry of Public Works, 2008 (in Turkish).

[23] Anon. Energy Efficiency Law, Ankara: Ministry of Public Works, 2007 (in Turkish).

[24]Anon. Building Energy Performance Regulation, Ankara: Ministry of Public Works,2008(in Turkish). 